\title{
Analisis Rasio Likuiditas, Rasio Profitabilitas dan Earning Per Share pada PT. Hanjaya Mandala Sampoerna Tbk di Bursa Efek Indonesia Periode 2014-2017
}

\author{
Muryati, Kasiyati Yunita W \\ Sekolah Tinggi Ilmu Ekonomi Graha Karya, Muara Bulian Jambi
}

\begin{abstract}
Analysis of the company's financial statements is needed to determine the company's ability to overcome the company's financial problems and make quick and right decisions. Liquidity ratio analysis is a ratio used to measure a company's ability to meet its short-term obligations. Profitability ratio analysis is a ratio used to measure a company's ability to generate profits derived from sales. Earning Per Share is a form of giving benefits to shareholders from each share owned. This study aims to determine the results of the analysis of the solvency, liquidity, profitability and Earning Per Share ratio of PT. Hanjaya Mandala Sampoerna TBK on the Indonesia Stock Exchange for the period of 2014 - 2017. The data used are secondary data in the form of financial statements of PT. Hanjaya Mandala Sampoerna TBK on the Indonesia Stock Exchange for the period of 2014 - 2017. Liquidity ratios are intended for short-term debt which in this research year can show that PT. HM Sampoerna Tbk is very able to meet these obligations, after that the Profitability Ratio is set aside for company profits which in this research year can generate profits even though its development fluctuates with a downward trend. And the last Earning Per Share which is limited to the price per common stock outstanding in this research year can be seen a nominal stock price split. With this research PT.Hanjaya Mandala Sampoerna, Tbk still needs to improve its asset management as much as possible.
\end{abstract}

Keywords: Analysis of Liquidity Ratio, Profitability and Earning Per Share

\section{PENDAHULUAN}

Dunia usaha yang berjalan kompetitif seiring berkembangnya berbagai jenis usaha menuntut setiap perusahaan untuk dapat mengolah dan melaksanakan manajemen perusahaan menjadi lebih profesional. Bertambahnya pesaing disetiap saat, menuntut setiap perusahaan harus berusaha menampilkan yang terbaik, dalam segi kinerja perusahaan, juga strategi yang matang dalam segala segi termasuk dalam kinerja keuangan.

Perusahaan dalam melakukan kegiatan operasional diperlukan kinerja untuk melihat hasil kegiatan usahanya dengan menggunakan analisis laporan keuangan, khususnya pemilik perusahaan dan manajemen, untuk dapat mudah memahami sebuah laporan keuangan, diperlukan suatu analisis yang dilakukan dengan menggunakan rasio-rasio keuangan. Analisis rasio laporan keuangan yang digunakan adalah analisis rasio likuiditas, analisis rasio profitabilitas dan Earning Per Share PT. Hanjaya Mandala Sampoerna TBK..

\section{Landasan Teori}

Rasio (ratio) disebut sebagai perbandingan jumlah, dari satu jumlah dengan jumlah lainnya itulah dilihat perbandingannya dengan harapan nantinya akan ditemukan jawaban yang selanjutnya itu dijadikan bahan kajian untuk dianalisis dan diputuskan. Rasio keuangan atau financial ratio ini sangat penting gunanya melakukan analisa terhadap laporan keuangan perusahaan".Fahmi (2014 : 107) Rasio Keuangan adalah angka yang diperoleh dari hasil perbandingan dari satu pos laporan keuangan dengan pos lainnya yang mempunyai hubungan yang relevan dan signifikan (berarti). Misalnya antara utang dan modal, antara kas dan total aset, antara harga pokok produksi dengan total penjualan dan sebagainya". (Syafri Harahap, 2013: 297):"

\section{Rasio Likuiditas}

Menurut Irham Fahmi (2016:65) Rasio Likuiditas yaitu kemampuan suatu perusahaan memenuhi kewajiban jangka pendeknya secara tepat waktu. Semakin besar Current Ratio, Quick Ratio (acit tes ratio), Net Working Capital Ratio dan Cash Flow Liquidity Ratio maka menunjukkan semakin tinggi kemampuan perusahaan dalam memenuhi kewajiban jangka pendek.

Selanjutnya Menurut Kasmir (2014:65) Rasio likuiditas adalah rasio yang menggambarkan kemampuan perusahaan untuk menyelesaikan kewajiban jangka pendeknya (kurang dari satu tahun). Perusahaan yang mempunyai cukup kemampuan untuk membayar utang jangka pendek disebut perusahaan yang likuid begitupun sebaliknya perusahaan yang tidak mempunyai kemampuan untuk membayar utang jangka pendek disebut perusahaan yang ilikuid. Adapun yang tergabung dalam rasio ini adalah rasio lancar (current ratio), rasio cepat (quick ratio) dan rasio kas (cash ratio).

\section{Current Ratio (CR)}

Pengertian Current Ratio menurut M. Fraser Lyn dan Aileen Ormiston dalam buku Irham Fahmi (2016:66) Rasio Lancar (Current Ratio) adalah Ukuran yang umum digunakan atas solvensi jangka pendek, kemampuan suatu perusahaan memenuhi suatu kebutuhan utang ketika jatuh tempo. 
Dan Menurut Kasmir (2014:72) current ratio adalah rasio yang digunakan untuk mengukur kemampuan perusahaan dalam membayar kewajiban jangka pendek atau utang yang segera jatuh tempo pada saat ditagih secara keseluruhan. Dalam praktiknya, rasio lancar dengan standar $200 \%$ (2:1) yang terkadang sudah dianggap sebagai ukuran yang cukup baik atau memuaskan bagi suatu perusahaan.

Sedangkan menurut Mulyawan (2015:52) current ratio adalah rasio yang mengukur seberapa jauh aktiva lancar perusahaan bisa dipakai untuk memenuhi kewajiban lancarnya. Dan Kasmir (2016:134) menerangkan bahwa: "Rasio lancar atau (current ratio) merupakan rasio untuk mengukur kemampuan perusahaan dalam membayar kewajiban jangka pendek atau utang yang segera jatuh tempo pada saat ditagih secara keseluruhan".

Selanjutnya menurut Mamduh (2016:75) menerangkan bahwa: "Rasio lancar mengukur kemampuan perusahaan memenuhi utang jangka pendeknya dengan menggunakan aktiva lancarnya (aktiva yang akan berubah menjadi kas dalam waktu satu tahun atau satu siklus bisnis)".

\section{Quick Ratio (Acit Test Ratio)}

Quick Ratio (Acit Test Ratio) sering disebut dengan istilah rasio cepat. Menurut Bambang Riyanto dalam buku Irham Fahmi (2016:71) Apabila kita menggunakan "acit test ratio" untuk menentukan tingkat likuiditas, maka secara umum dapatlah dikatakan bahwa suatu perusahaan yang mempunyai "Quick Ratio" kurang dari 1:1 atau 100\% dianggap kurang baik tingkat likuiditasnya.

Dan Quick ratio (acid test ratio) lebih baik dalam mengukur kemampuan perusahaan dalam memenuhi kewajiban jangka pendeknya, karena dalam perhitungannya semua unsur-unsur persediaan dikurangkan atau dianggap tidak digunakan untuk membayar utang jangka pendek (Mamduh dan Abdul Halim, 2014:202).

\section{Net Working Capital Ratio}

Net Working Capital Ratio atau Rasio Modal Kerja Bersih. Menurut Irham Fahmi (2016:71) modal kerja merupakan suatu ukuran dari likuiditas perusahaan. Sumber modal kerja adalah: (1) Pendapatan bersih, (2) Peningkatan kewajiban yang tidak lancar, (3) Kenaikan ekuitas pemegang saham, dan (4) penurunan aktiva yang tidak lancar.

Dan menurut Kasmir Perputaran Modal Kerja (Working Capital Ratio) merupakan salah satu rasio untuk mengukur atau menilai keefektifan modal kerja perusahaan selama periode tertentu. Artinya seberapa banyak modal kerja berputar selama suatu periode atau dalam suatu periode. Untuk mengukur rasio ini, membandingkan antara penjualan dengan modal kerja atau rata-rata modal kerja.

\section{Cash Flow Liquidity Ratio}

Cash Flow Liquidity Ratio atau disebut juga dengan rasio likuiditas arus kas. Menurut Irham Fahmi (2016:71) dalam Cash Flow Liquidity Ratio ini bahwa jika rasio ini terjadi peningkatan maka itu menunjukkan kemampuan perusahaan dalam mengatasi berbagai permasalahan kewajiban jangka pendeknya, namun sebaliknya jika arus kas menggambarkan terjadinya penurunan maka ini menunjukkan bahwa perusahaan akan bermasalah atau harus menerapkan alternatif strategi dalm mengatasi berbagai hal yang menyangkut dengan kebutuhan jangka pendek.

Dan menurut Kasmir (2014:134) Rasio Perputaran Kas (cash turn over) berfungsi untuk mengukur tingkat kecukupan modal kerja perusahaan yang dibutuhkan untuk membayar tagihan dan membiayai penjualan. Artinya rasio ini digunakan untuk mengukur tingkat ketersediaan kas untuk membayar tagihan (utang) dan biaya-biaya yang berkaitan dengan penjualan.

\section{Rasio Profitabilitas}

Rasio Profitabilitas menurut Irham Fahmi (2016:80) adalah rasio yang mengukur efektivitas manajemen secara keseluruhan yang ditunjukkan oleh besar kecilnya tingkat keuntungan yang diperoleh dalam hubungannya dengan penjualan maupun investasi. Menurut Irham Fahmi (2016:80) Rasio Profitabilitas secara umum ada 4 (empat), yaitu Gross Profit Margin (Margin Laba Kotor), Net Profit Margin (Pendapatan Terhadap Penjualan), Return On Investment (Pengembalian Investasi), dan Return on Equity (Laba Atas Equity) atau di beberapa referensi di sebut juga dengan Rasio Total Asset Turn Over (Perputaran Total Asset). Dalam penelitian ini, rasio profitabilitas ke empatnya digunakan.

\section{Gross Profit Margin}

Menurut Lyn M. Fraser dan Aileen Ormiston dalam buku Irham Fahmi (2016:80) Margin laba kotor, yang memperlihatkan hubungan antara penjualan dan beban pokok penjualan, mengukur kemampuan sebuah perusahaan untuk mengendalikan biaya persediaan atau biaya operasi barang maupun untuk meneruskan kenaikan harga lewat penjualan kepada pelanggan. Atau lebih jauh menurut Joel G. Siegel dan Jae K. Shim dalam buku Irham Fahmi (2016:81) Persentase dari sisa penjualan setelah sebuah perusahaan membayar barangnya; juga disebut margin keuntungan kotor (Gross Profit Margin).

Dan menurut Irham Fahmi (2015:136) Gross Profit Margin (GPM) merupakan perbandingan antara laba kotor dengan penjualan. Apabila harga pokok penjualan meningkat maka GPM akan meningkat dan 
begitu pula sebaliknya, apabila harga pokok penjualan menurun maka GPM akan menurun.

\section{Net Profit Margin}

Menurut Joel G. Siegel dan Jae K. Shim dalam buku Irham Fahmi (2016:81) (1). Margin laba bersih sama dengan laba bersih dibagi dengan penjualan bersih. Ini menunjukkan kestabilan kesatuan untuk menghasilkan perolehan pada tingkat penjualan khusus. Dengan memeriksa margin laba dan norma industri sebuah perusahaan pada tahun-tahun sebelumnya, kita dapat menilai efisiensi operasi dan strategi penetapan harga serta status persaingan perusahaan dengan perusahaan lain dalam industri tersebut. (2). Margin laba kotor sama dengan laba kotor dibagi laba bersih. Margin laba yang tinggi lebih disukai karena menunjukkan bahwa perusahaan mendapat hasil yang lebih baik yang melebihi harga pokok penjualan.

Dan menurut Irham Fahmi (2015:136) Net Profit Margin (NPM), merupakan rasio yang digunakan untuk mengukur margin laba atas penjualan, rasio ini akan menggambarkan penghasilan bersih perusahaan berdasarkan total penjualan.

\section{Return On Investment (ROI)}

Menurut Irham Fahmi (2016:82) mengemukakan: " Return On Investment (ROI) atau pengembalian investasi, bahwa di beberapa referensi lainya rasio ini juga ditulis dengan return on total asset (ROA). Rasio ini melihat sejauh mana investasi yang telah ditanamkan mampu memberikan pengembalian keuntungan sesuai yang diharapkan. Dan investasi tersebut sebenarnya sama dengan asset perusahaan yang ditanamkan atau ditempatkan.

Dan pengertian Return on Investment (ROI) menurut Kasmir (2015:198) Rasio ini merupakan rasio yang menunjukkan hasil (return) atas jumlah aktiva yang digunakan dalam perusahaan. ROI juga merupakan suatu ukuran tentang efektivitas manajemen dalam mengelola investasinya.

\section{Return on Equity}

Menurut Irham Fahmi (2016:82) Rasio ini mengkaji sejauh mana suatu perusahaan mempergunakan sumber daya yang dimiliki untuk mampu memberikan laba dan ekuitas. Dan Return on Equity (ROE) menurut Harahap (2015:305) Return on Equity merupakan perbandingan antara laba bersih sesudah pajak dengan total ekuitas. Return on Equity merupakan suatu pengukuran dari penghasilan (income) yang tersedia bagi para pemilik perusahaan (baik pemegang saham biasa maupun pemegang saham preferen) atas modal yang mereka investasikan di dalam perusahaan.

Selenjutnya Return on Equity (ROE) menurut Kasmir (2015:104) Rasio ini merupakan rasio yang digunakan untuk mengukur laba bersih sesudah pajak dengan modal sendiri. Rasio ini menunjukkan efisiensi penggunaan modal sendiri. Semakin tinggi rasio ini, semakin baik. Artinya posisi pemilik perusahaan semakin kuat, demikian pula sebaliknya.

\section{Earning Per Share}

Menurut Irham Fahmi (2016:83) Earning Per Share atau pendapatan perlembar saham adalah bentuk pemberian keuntungan yang diberikan kepada para pemegang saham dari setiap lembar saham yang dimiliki. Adapun menurut Van Horne dan Wachowicz dalam buku Irham Fahmi (2016:83) Earning Per Share adalah "Earning After Taxes (EAT) dividend by the number of common share outstanding." dividen dengan jumlah saham biasa yang beredar.

Dan menurut Kasmir (2013:207), mendefinisikan Earning Per Share (EPS) sebagai berikut : "Rasio laba per lembar saham atau disebut juga rasio nilai buku, merupakan rasio untuk mengukur keberhasilan manajemen dalam mencapai keuntungan bagi pemegang saham."

\section{METODE PENELITIAN Metoda Analisa}

Data-data yang bersumber pada Studi Kepustakaan (Library Research) Yaitu mengumpulkan data-data yang berkaitan dengan mempelajari berbagai bentuk bahan-bahan tertulis yang berkaitan dengan penelitian untuk mendapatkan informasi mengenai analisis rasio laporan keuangan, yang didapat dari data sekunder.

\section{Alat Analisa \\ Rasio Likuiditas}

1. Current Ratio $(\mathrm{CR})=\frac{\text { Current Assets }}{\text { Current Liabilities }}$

2. Quick Ratio (Acit Test Ratio) $=\frac{\text { Current Assets-Inventories }}{\text { Current Liabilities }}$

3. Net Working Capital Ratio $=$ Current Assets - Current Liabilities

4. Cash Flow Liquidity Ratio $=\frac{\text { Cash }+ \text { Commercial Paper }+ \text { CFO }}{\text { Curren Liabilities }}$

\section{Rasio Profitabilitas}

1. Gross Profit Margin $=\frac{\text { Sales }- \text { Cost of Good Sold }}{\text { Sales }}$

2. Net Profit Margin $=\frac{\text { Earning After Tax }(E A T)}{\text { Sales }}$

3. Return On Investment (ROI) $=\frac{\text { Earning After } \operatorname{Tax}(E A T)}{\text { Total Asset }}$

4. Return on Equity $(\mathrm{ROE})=\frac{\text { Earning After } \operatorname{Tax}(E A T)}{\text { Shareholders' }^{\text {Equity }}}$

Earning Per Share (EPS)

Earning Per Share (EPS): Earning After Tax (EAT)

\section{HASIL DAN PEMBAHASAN}

Rasio Likuiditas 


\section{Rasio Lancar (Current Ratio)}

Rasio Lancar (Current Ratio) suatu ukuran yang umum digunakan atas solvensi jangka pendek, kemampuan suatu perusahaan memenuhi suatu kebutuhan utang ketika jatuh tempo, maka dapat kita lihat, kemampuan perusahaan memenuhi suatu kebutuhan utang ketika jatuh tempo

Tabel 1. Perhitungan Curren Ratio

\begin{tabular}{|c|c|c|c|}
\hline Tahun & Aset Lancar & Hutang Lancar & Curren Ratio \\
\hline 2014 & $20,777,514$ & $20,777,514$ & 1.527 \\
\hline 2015 & $29,807,330$ & $29,807,330$ & 6.567 \\
\hline 2016 & $33,647,496$ & $33,647,496$ & 5.234 \\
\hline 2017 & $34,180,353$ & $34,180,353$ & 5.272 \\
\hline
\end{tabular}

Sumber: IDX(data diolah)

Berdasarkan tabel 1 dapat diketahui bahwa Pada tahun 2014 Setiap Rp 1 hutang lancar dijamin oleh Rp 1.527 harta lancar atau perbandingannya antara aktiva lancar dengan hutang lancar adalah $1.527: 1$, Pada tahun 2015 Setiap Rp 1 hutang lancar dijamin oleh Rp 6.567 harta lancar atau perbandingannya antara aktiva lancar dengan hutang lancar adalah 6.567 : 1, Pada tahun 2016 Setiap Rp 1 hutang lancar dijamin oleh Rp 5.234 harta lancar atau perbandingannya antara aktiva lancar dengan hutang lancar adalah $5.234:$ 1, Pada tahun 2017 Setiap Rp1 hutang lancar dijamin oleh Rp 5.272 harta lancar atau perbandingannya antara aktiva lancar dengan hutang lancar adalah $5.272: 1$. Menunjukkan bahwa Aktiva Lancar mampu untuk membayar hutang lancar, dengan ratio terbaik nya adalah 2:1 (Aktiva lancar: Hutang Lancar).

\section{Rasio Cepat (Quick Ratio)}

Merupakan rasio yang menunjukkan kemampuan perusahaan dalam memenuhi atau membayar kewajiban atau utang lancar (utang jangka pendek) dengan aktiva lancar tanpa memperhitungkan nilai persediaan (inventory).

Tabel 2. Perhitungan Rasio Cepat (Quick Ratio)

\begin{tabular}{lcccc}
\hline Tahun & Aset Lancar & Persediaan & Hutang Lancar & Quick Ratio \\
\hline 2014 & $20,777,514$ & $17,431,586$ & $13,600,230$ & 0.246 \\
2015 & $29,807,330$ & $19,071,523$ & $4,538,674$ & 2.365 \\
2016 & $33,647,496$ & $19,442,023$ & $6,428,478$ & 2.209 \\
2017 & $34,180,353$ & $18,023,238$ & $6,482,969$ & 2.492 \\
\hline
\end{tabular}

Sumber : IDX (data diolah)

Berdasarkan tabel 2 dapat diketahui bahwa perubahan Quick Ratio pada PT. Hanjaya Mandala Sampoerna Tbk. Pada tahun 2014 Setiap Rp 1 hutang lancar dijamin oleh $\mathrm{Rp} 0.246$ harta lancar tanpa persediaan atau perbandingannya antara aktiva lancar dengan hutang lancar adalah 0.246 : 1, Pada tahun 2015 Setiap Rp 1 hutang lancar dijamin oleh Rp 2.365 harta lancar tanpa persediaan atau perbandingannya antara aktiva lancar dengan hutang lancar adalah 2.365: 1, Pada tahun 2016 Setiap Rp 1 hutang lancar dijamin oleh Rp 2.209 harta lancar tanpa persediaan atau perbandingannya antara aktiva lancar dengan hutang lancar adalah 2.209 : 1, Pada tahun 2017 Setiap Rp 1 hutang lancar dijamin oleh Rp 2.492 harta lancar tanpa persediaan atau perbandingannya antara aktiva lancar dengan hutang lancar adalah $2.492: 1$. Ini membuktikan bahwa pada tahun pertama penelitian perusahaan belum mampu untuk memenuhi kewajiban jangka pendek nya, dikarenakan pada perhitungan quick ratio, Inventories (Persediaan) tidak dimasukkan dalam hitungannya.

\section{Net Working Capital Ratio atau Rasio Modal Kerja Bersih}

Net Working Capital Ratio atau Rasio Modal Kerja Bersih. Dan sumber modal kerja adalah: (1) Pendapatan bersih, (2) Peningkatan kewajiban yang tidak lancar, (3) Kenaikan ekuitas pemegang saham, dan (4) penurunan aktiva yang tidak lancar.

Tabel 3. Perhitungan Net Working Capital Ratio

\begin{tabular}{lccc}
\hline Tahun & Aset Lancar & Hutang Lancar & Net Working Capital Ratio \\
\hline 2014 & $20,777,514$ & $13,600,230$ & $7,177,284$ \\
2015 & $29,807,330$ & $4,538,674$ & $25,268,656$ \\
2016 & $33,647,496$ & $6,428,478$ & $27,219,018$ \\
2017 & $34,180,353$ & $6,482,969$ & $27,697,384$ \\
\hline
\end{tabular}

Sumber: IDX (data diolah) 
Berdasarkan tabel 3 dapat diketahui bahwa perubahan Net Working Capital Ratio pada PT. Hanjaya Mandala Sampoerna Tbk. Pada tahun 2014 Setiap Rp 1 hutang lancar dijamin oleh Rp 7,177 dalam jutaan rupiah harta lancar atau perbandingannya antara aktiva lancar dengan hutang lancar adalah 7,177 : 1 yang merupakan modal kerja bersih dari perusahaan. Pada tahun 2015 Setiap Rp 1 hutang lancar dijamin oleh Rp 25,268 dalam jutaan rupiah harta lancar atau perbandingannya antara aktiva lancar dengan hutang lancar adalah 25,268:1 yang merupakan modal kerja bersih dari perusahaan. Pada tahun 2016 Setiap Rp 1 hutang lancar dijamin oleh Rp 27,219 dalam jutaan rupiah harta lancar atau perbandingannya antara aktiva lancar dengan hutang lancar adalah 27,219: 1 yang merupakan modal kerja bersih dari perusahaan. Pada tahun 2017 Setiap Rp 1 hutang lancar dijamin oleh Rp 27,697 dalam jutaan rupiah harta lancar atau perbandingannya antara aktiva lancar dengan hutang lancar adalah 27,697 : 1 yang merupakan modal kerja bersih dari perusahaan. Ini menunjukkan bahwa PT. HM Sampoerna Tbk memiliki Net Working Capital Ratio (Rasio Modal Kerja Bersih) yang sangat baik dengan di tunjukkan pada tahun 20142017 terjadi peningkatan yang terus menerus. Yang disebabkan oleh keseimbangan perkembangan aset lancar dan hutang lancar membuat rasio modal kerja bersih ini berkembang sesuai dengan harapan perusahaan.

\section{Cash Flow Liquidity Ratio}

Cash Flow Liquidity Ratio atau disebut juga dengan rasio likuiditas arus kas. Bahwa jika rasio ini terjadi peningkatan maka itu menunjukkan kemampuan perusahaan dalam mengatasi berbagai permasalahan kewajiban jangka pendeknya, namun sebaliknya jika arus kas menggambarkan terjadinya penurunan maka ini menunjukkan bahwa perusahaan akan bermasalah atau harus menerapkan alternatif strategi dalm mengatasi berbagai hal yang menyangkut dengan kebutuhan jangka pendek.

Tabel 4. Perhitungan Cash Flow Liquidity Ratio

\begin{tabular}{lcccc}
\hline Tahun & Kas & Arus Kas dari Aktivitas Operasi & Hutang Lancar & Cash Flow Liquidity Ratio \\
\hline 2014 & 65,086 & $11,103,195$ & $13,600,230$ & 0.821 \\
2015 & $1,718,738$ & 811,163 & $4,538,674$ & 0.557 \\
2016 & $5,056,183$ & $14,076,579$ & $6,428,478$ & 2.976 \\
2017 & $7,501,737$ & $15,376,315$ & $6,482,969$ & 3.528 \\
\hline
\end{tabular}

Sumber: IDX(data diolah)

Berdasarkan tabel 4 dapat diketahui bahwa perubahan Cash Flow Liquidity pada PT. Hanjaya Mandala Sampoerna Tbk. Pada tahun 2014 Setiap Rp 1 hutang lancar dijamin oleh $\mathrm{Rp} 0.821$ harta lancar dari arus kas atau perbandingannya antara aktiva lancar dengan hutang lancar adalah $0.821: 1$ yang merupakan tingkat kesanggupan perusahaan dalam menghadapi kewajiban jangka pendeknya.

Pada tahun 2015 Setiap Rp 1 hutang lancar dijamin oleh Rp 0.557 harta lancar dari arus kas atau perbandingannya antara aktiva lancar dengan hutang lancar adalah 0.557 : 1 yang merupakan tingkat kesanggupan perusahaan dalam menghadapi kewajiban jangaka pendeknya.

Pada tahun 2016 Setiap Rp 1 hutang lancar dijamin oleh $\mathrm{Rp} 2.976$ harta lancar dari arus kas atau perbandingannya antara aktiva lancar dengan hutang lancar adalah 2.976 : 1 yang merupakan tingkat kesanggupan perusahaan dalam menghadapi kewajiban jangaka pendeknya.

Pada tahun 2017 Setiap Rp 1 hutang lancar dijamin oleh $\mathrm{Rp} 3.528$ harta lancar dari arus kas atau perbandingannya antara aktiva lancar dengan hutang lancar adalah $3.528: 1$ yang merupakan tingkat kesanggupan perusahaan dalam menghadapi kewajiban jangaka pendeknya. Ini menunjukkan bahwa PT. HM
Sampoerna Tbk memiliki Cash Flow Liquidity yang baik dari tahun 2014 ke 2017, sebab sebagian besar perusahaan lainya hanya mampu menjamin hutang lancar nya sebesar 0.5 : 1 . Pada PT. HM Sampoerna Tbk mampu lebih dari 0.5: 1 .

\section{Rasio Profitabilitas}

Rasio Profitabilitas dan penulis menggunakan data keuangan PT. Hanjaya Mandala Sampoerna Tbk. Berdasarkan hasil Gross Profit Margin, Net Profit Margin, Return On Investmenet, dan Return on Equity yang akan dibahas pada penelitian ini maka dapat diketahui perkembangan dan perubahan Rasio Profitabilitas pada PT. Hanjaya Mandala Sampoerna Tbk periode tahun 2014-2017.

\section{Gross Profit Margin}

Margin laba kotor, yang memperlihatkan hubungan antara penjualan dan beban pokok penjualan, mengukur kemampuan sebuah perusahaan untuk mengendalikan biaya persediaan atau biaya operasi barang maupun untuk meneruskan kenaikan harga lewat penjualan kepada pelanggan. Dan Persentase dari sisa penjualan setelah sebuah perusahaan membayar barangnya; juga disebut margin keuntungan kotor (Gross Profit Margin). 
Analisis Rasio Likuiditas, Rasio Profitabilitas dan Earning Per Share pada PT. Hanjaya Mandala Sampoerna Tbk di Bursa Efek Indonesia Periode 2014-2017

Tabel 5. Perhitungan Gross Profit Margin

\begin{tabular}{lccc}
\hline Tahun & Penjualan & Harga Pokok Penjualan & Gross Profit Margin \\
\hline 2014 & $80,690,139$ & $60,190,077$ & 0.254 \\
2015 & $89,069,306$ & $67,304,917$ & 0.244 \\
2016 & $95,466,657$ & $71,611,981$ & 0.249 \\
2017 & 99,091484 & $74,875,642$ & 0.244 \\
\hline
\end{tabular}

Sumber : IDX (data diolah)

Berdasarkan tabel 5 dapat diketahui bahwa perubahan Gross Profit Margin pada PT. Hanjaya Mandala Sampoerna Tbk. Pada tahun 2014 setiap Rp 1 penjualan PT. HM SAMPOERNA Tbk, 0.746 nya digunakan untuk menutupi HPP, sementara 0.254 nya digunakan untuk menutupi biaya umum. Dengan kata lain setiap Rp 1 penjualan PT. HM SAMPOERNA Tbk $74.6 \%$ nya digunakan untuk menutupi HPP, sementara $25.4 \%$ nya digunakan untuk menutupi biaya umum.

Pada tahun 2015 setiap Rp 1 penjualan PT. HM SAMPOERNA Tbk, 0.756 nya digunakan untuk menutupi HPP, sementara 0.244 nya digunakan untuk menutupi biaya umum. Dengan kata lain setiap Rp 1 penjualan PT. HM SAMPOERNA Tbk $75.6 \%$ nya digunakan untuk menutupi HPP, sementara $24.4 \%$ nya digunakan untuk menutupi biaya umum.

Pada tahun 2016 setiap Rp 1 penjualan PT. HM SAMPOERNA Tbk, 0.751 nya digunakan untuk menutupi HPP, sementara 0.249 nya digunakan untuk menutupi biaya umum. Dengan kata lain setiap Rp 1 penjualan PT. HM SAMPOERNA Tbk $75.1 \%$ nya digunakan untuk menutupi HPP, sementara $24.9 \%$ nya digunakan untuk menutupi biaya umum.

Pada tahun 2017 setiap Rp 1 penjualan PT. HM SAMPOERNA Tbk, 0.756 nya digunakan untuk menutupi HPP, sementara 0.244 nya digunakan untuk menutupi biaya umum. Dengan kata lain setiap Rp 1 penjualan PT. HM SAMPOERNA Tbk $75.6 \%$ nya digunakan untuk menutupi HPP, sementara $24.4 \%$ nya digunakan untuk menutupi biaya umum.

Ini menunjukkan bahwa Gross Profit Margin PT. HM SAMPOERNA Tbk dalam kondisi baik, karena semakin besar Gross Profit Margin semakin baik keadaan operasi perusahaan, karena hal ini menunjukkan bahwa harga pokok penjualan relative lebih rendah di bandingkan dengan penjualan. Demikian pula sebaliknya, semakin rendah Gross Profit Margin, semakin kurang baik operasi perusahaan.

\section{Net Profit Margin}

Margin laba bersih sama dengan laba bersih dibagi dengan penjualan bersih. Ini menunjukkan kestabilan kesatuan untuk menghasilkan perolehan pada tingkat penjualan khusus. Dengan memeriksa margin laba dan norma industri sebuah perusahaan pada tahuntahun sebelumnya, kita dapat menilai efisiensi operasi dan strategi penetapan harga serta status persaingan perusahaan dengan perusahaan lain dalam industri tersebut. Lalu Margin laba kotor sama dengan laba kotor dibagi laba bersih. Margin laba yang tinggi lebih disukai karena menunjukkan bahwa perusahaan mendapat hasil yang lebih baik yang melebihi harga pokok penjualan. Berikut tabel 6 yang berisi tentang perkembangan $\mathrm{Net}$ Profit Margin:

Tabel 6. Net Profit Margin

\begin{tabular}{lccc}
\hline Tahun & Laba Setelah Pajak & Penjualan & Net Profit Margin \\
\hline 2014 & $10,181,083$ & $80,690,139$ & 0.126 \\
2015 & $10,363,308$ & $89,069,306$ & 0.116 \\
2016 & $12,762,229$ & $95,466,657$ & 0.133 \\
2017 & $12,670,534$ & 99,091484 & 0.127 \\
\hline
\end{tabular}

Sumber : IDX (data diolah)

Berdasarkan tabel 6 dapat diketahui bahwa perubahan Net Profit Margin pada PT. Hanjaya Mandala Sampoerna Tbk Pada tahun 2014 setiap Rp 1 penjualan PT. HM SAMPOERNA Tbk, 0.874 nya digunakan untuk menutupi HPP, biaya umum, pajak, sementara untuk 0.126 nya merupakan laba bersih. Dengan kata lain setiap Rp 1 penjualan PT. HM SAMPOERNA Tbk $87.4 \%$ nya digunakan untuk menutupi HPP, biaya umum, pajak, sementara untuk $12.6 \%$ nya merupakan laba bersih.

Pada tahun 2015 setiap Rp 1 penjualan PT. HM SAMPOERNA Tbk, 0.884 nya digunakan untuk menutupi HPP, biaya umum, pajak, sementara untuk
0.116 nya merupakan laba bersih. Dengan kata lain setiap Rp 1 penjualan PT. HM SAMPOERNA Tbk $88.4 \%$ nya digunakan untuk menutupi HPP, biaya umum, pajak, sementara untuk $11.6 \%$ nya merupakan laba bersih.

Pada tahun 2016 setiap Rp 1 penjualan PT. HM SAMPOERNA Tbk, 0.867 nya digunakan untuk menutupi HPP, biaya umum, pajak, sementara untuk 0.133 nya merupakan laba bersih. Dengan kata lain setiap Rp 1 penjualan PT. HM SAMPOERNA Tbk $86.7 \%$ nya digunakan untuk menutupi HPP, biaya umum, pajak, sementara untuk $13.3 \%$ nya merupakan laba bersih. 
Pada tahun 2017 setiap Rp 1 penjualan PT. HM SAMPOERNA Tbk, 0.873 nya digunakan untuk menutupi HPP, biaya umum, pajak, sementara untuk 0.127 nya merupakan laba bersih. Dengan kata lain setiap Rp 1 penjualan PT. HM SAMPOERNA Tbk $87.3 \%$ nya digunakan untuk menutupi HPP, biaya umum, pajak, sementara untuk $12.7 \%$ nya merupakan laba bersih. Ini menunjukkan pada tahun penelitian bahwasannya Net Profit Margin PT. HM SAMPOERNA Tbk memiliki laba bersih yang cukup baik, karena
Semakin tinggi Net Profit Margin, semakin baik hasil operasi perusahaan.

\section{Return On Investment}

Return On Investment (ROI) atau pengembalian investasi, Rasio ini melihat sejauh mana investasi yang telah ditanamkan mampu memberikan pengembalian keuntungan sesuai yang diharapkan. Dan investasi tersebut sebenarnya sama dengan asset perusahaan yang ditanamkan atau ditempatkan.”

Tabel 7. Perhitungan Return On Investment

\begin{tabular}{lccc}
\hline Tahun & Laba Setelah Pajak & Total Aset & Return On Investment \\
\hline 2014 & $10,181,083$ & $28,380,630$ & 0.358 \\
2015 & $10,363,308$ & $38,010,724$ & 0.272 \\
2016 & $12,762,229$ & $42,508,277$ & 0.300 \\
2017 & $12,670,534$ & $43,141,063$ & 0.293 \\
\hline
\end{tabular}

Sumber : IDX (data diolah)

Berdasarkan tabel 7 dapat diketahui bahwa perubahan Return On Investment pada PT. Hanjaya Mandala Sampoerna Tbk. Pada Tahun 2014 untuk setiap Rp 1 investasi yang ditanamkan di PT. HM SAMPOERNA Tbk, perusahaan mendapatkan penghasilan bersih sebesar 0.358. Pada Tahun 2015 untuk setiap Rp 1 investasi yang ditanamkan di PT. HM SAMPOERNA Tbk, perusahaan mendapatkan penghasilan bersih sebesar 0.272. Pada Tahun 2016 untuk setiap Rp 1 investasi yang ditanamkan di PT. HM SAMPOERNA Tbk, perusahaan mendapatkan penghasilan bersih sebesar 0.300. Pada Tahun 2017 untuk setiap Rp 1 investasi yang ditanamkan di PT. HM SAMPOERNA Tbk, perusahaan mendapatkan penghasilan bersih sebesar 0.293. Ini menunjukkan pada tahun penelitian bahwa tingkat return (penghasilan) yang di peroleh pemilik perusahaan atas modal yang di investasikan sudah cukup baik, karena semakin tinggin return atau penghasilan yang diperoleh semakin baik kedudukan/posisi pemilik perusahaan. Untuk Perubahan Return on Equity (ROE) pada PT. Hanjaya Mandala Sampoerna Tbk.di Bursa Efek Indonesia periode 20142017 dapat kita lihat sebagai berikut.

\section{Return on Equity}

Rasio ini mengkaji sejauh mana suatu perusahaan mempergunakan sumber daya yang dimiliki untuk mampu memberikan laba dan ekuitas, dapat dilihat pada tabel 8 sebagai berikut:

Tabel 8. Perhitungan Return On Equity

\begin{tabular}{lrrr}
\hline Tahun & Laba Setelah Pajak & Modal Sendiri & Return On Equity \\
\hline 2014 & $10,181,083$ & $13,498,114$ & 0.754 \\
2015 & $10,363,308$ & $32,016,060$ & 0.323 \\
2016 & $12,762,229$ & $34,175,014$ & 0.373 \\
2017 & $12,670,534$ & $34,112,985$ & 0.371 \\
\hline
\end{tabular}

Sumber : IDX (data diolah)

Berdasarkan tabel 8 dapat diketahui bahwa perubahan Return on Equity pada PT. Hanjaya Mandala Sampoerna Tbk. Pada Tahun 2014 untuk setiap Rp. 1 investasi yang ditanamkan di PT. HM SAMPOERNA Tbk, investor mendapatkan tingkat pengembalian sebesar 0.754. Pada Tahun 2015 untuk setiap Rp. 1 investasi yang ditanamkan di PT. HM SAMPOERNA Tbk, investor mendapatkan tingkat pengembalian sebesar 0.323. Pada Tahun 2016 untuk setiap Rp. 1 investasi yang ditanamkan di PT. HM SAMPOERNA Tbk, investor mendapatkan tingkat pengembalian sebesar 0.373. Pada Tahun 2017 untuk setiap Rp. 1 investasi yang ditanamkan di PT. HM SAMPOERNA Tbk, investor mendapatkan tingkat pengembalian sebesar 0.371. Ini menunjukkan bahwa tingkat return (penghasilan) yang di peroleh investor atas modal yang di investasikan sudah cukup baik, karena semakin tinggin return atau penghasilan yang diperoleh semakin baik kedudukan/posisi Investor.

\section{Earning Per Share}

Earning Per Share atau pendapatan perlembar saham suatu bentuk pemberian keuntungan yang diberikan kepada para pemegang saham dari setiap lembar saham yang dimiliki. Dalam laporan keuangan PT. HM SAMPOERNA, Earning Per Share (EPS) telah terlampirkan pada setiap tahunnya. Berikut pada tabel 9 
Analisis Rasio Likuiditas, Rasio Profitabilitas dan Earning Per Share pada PT. Hanjaya Mandala Sampoerna Tbk di Bursa Efek Indonesia Periode 2014-2017

Perkembangan Earning Per Share data yang telah tersaji pada setiap laporan keuangan tahunan perusahaan:

Tabel 9. Perhitungan Earning Per Share

\begin{tabular}{lccc}
\hline Tahun & Laba Setelah Pajak & $\mathbf{J}_{\mathbf{s b}}$ & EPS \\
\hline 2014 & $10,181,083$ & $4,415.04$ & 2,306 \\
2015 & $10,363,308$ & $111,433.41$ & 93 \\
2016 & $12,762,229$ & $116,020.26$ & 110 \\
2017 & $12,670,534$ & $116,243.43$ & 109 \\
\hline
\end{tabular}

Sumber : IDX (data diolah)

Berdasarkan tabel 9 dapat diketahui bahwa Perkembangan Earning Per Share pada PT. Hanjaya Mandala Sampoerna Tbk. Pada Tahun 2014 Earning Per Share atau harga perlembar saham biasa yang beredar dalam rupiah penuh pada PT. HM SAMPOERNA Tbk, senilai Rp 2.306 per lembar saham dan dilusian (Rupiah Penuh).

Pada Tahun 2015 Earning Per Share atau harga perlembar saham biasa yang beredar dalam rupiah penuh pada PT. HM SAMPOERNA Tbk, sebelum terjadi pemecahan nominal saham senilai Rp 2.326 per lembar saham dan dilusian (Rupiah Penuh) lalu setelah pemecahan nominal saham menjadi Rp 93 per lembar saham dan dilusian (Rupiah Penuh) dan data yang dipakai peneliti adalah data setelah pemecahan nominal saham yang merupakan data terbaru untuk tahun 2015, yang kembali di tampilkan pada laporan tahunan perusahaan tahun 2016.

Pada Tahun 2016 Earning Per Share atau harga perlembar saham biasa yang beredar dalam rupiah penuh pada PT. HM SAMPOERNA Tbk, senilai Rp 110 per lembar saham dan dilusian (Rupiah Penuh). Pada Tahun 2017 Earning Per Share atau harga perlembar saham biasa yang beredar dalam rupiah penuh pada PT. HM SAMPOERNA Tbk, senilai Rp 109 per lembar saham dan dilusian (Rupiah Penuh).

Ini menunjukkan bahwa kemampuan perusahaan dalam pemberian keuntungan yang diberikan kepada para pemegang saham dari setiap lembar saham yang dimiliki sudah cukup baik dengan bukti bahwa pada tahun penelitian PT. HM SAMPOERNA Tbk, dapat memberikan keuntungan kepada pemegang saham dari setiap lembar saham yang dimiliki.

\section{SIMPULAN}

Dari data yang penulis dapat selama melakukan penelitian, penulis dapat menarik kesimpulan sebagai berikut:

1. Rasio Likuiditas (keamampuan perusahaan dalam memenuhi kewajiban jangka pendek) sangat baik, dengan dibuktikan dari Current Ratio, Quick Ratio, Net Working Capital Ratio dan Cash Flow Liquidity Ratio dari tahun 2014-2017 mengalami fluktuasi dengan kecendrungan meningkat.

2. Rasio Profitabilias yang meliputi Gross Profit Margin, Net Profit Margin, Return On Investment dan Return on Equity dari tahun 2014-2017 mengalami fluktuasi dengan kecendrungan menurun pada setiap tahunnya, namun pada tahun penelitian ini perusahan tetap memperoleh profit pada setiap tahunnya.

3. Earning Per Share Ini menunjukkan bahwa kemampuan perusahaan dalam pemberian keuntungan yang diberikan kepada para pemegang saham dari setiap lembar saham yang dimiliki sudah cukup baik dengan bukti bahwa pada tahun penelitian PT. HM SAMPOERNA Tbk, dapat memberikan keuntungan kepada pemegang saham dari setiap lembar saham yang dimiliki.

\section{DAFTAR PUSTAKA}

Fahmi, Irham (2016) Analisis Laporan Keuangan, Bandung : Alfabeta

Hanafi, Mamduh M dan Abdul Halim (2014) Analisis Laporan Keuangan, Yogyakarta : UPP STIM YKPN

Harahap, Sofyan Syafri (2013) Analisis Kritis Atas Laporan Keuangan, Jakarta : Rajawali Pers

Hermanto, Bambang., dan Mulyo agung (2015) Analisa Laporan Keuangan, Jakarta : Lentera Ilmu Cendekia

Kasmir (2014) Analisis Laporan Keuangan, Jakarta : Rajawali Pers,

http://britama.com/index.php/2012/11/sejarah-danprofil-singkat-hmsp/ (diakses pada tanggal 03 Juli $\underline{2018)}$

http://adaddanuarta.blogspot.com/2014/11/aktiva-tetapmenurut-para-ahli.html (diakses pada tanggal 05 Juli 2018)

www.sampoerna.com

www.google.com(pendapat-para-ahli) 